\title{
Volunteering in the Context of Social Work - Historical Connection and Perspectives
}

\begin{abstract}
Social and voluntary work are connected historically. The relationship between social and voluntary work has undergone specific development. Contemporary values of social and voluntary work are based on principles of democracy and human rights and their aim is to promote a socially cohesive and just society. The goal of the contribution is to analyze the perspectives of volunteering in the context of social work. In the first section the historical connection between voluntary and social work is analyzed. In the second section attention is paid to changes in social and voluntary work in relation to the modernization process of society and possibilities and perspectives of future cooperation between social and voluntary work are outlined.
\end{abstract}

Keywords: social work, voluntary work, community, professionalization

\section{Introduction}

Voluntary and social work have common historical roots, a shared philosophical and ethical background and sphere of activity. They are also heavily influenced by the political and cultural context in which they are developing. Nowadays, both voluntary as well as social work are being confronted with social trends related to the modernisation of society such as globalisation, technological development, demographic changes, changes in civil society, the rise of post-modern values and changes in family and work. In the field of social as well as in voluntary work these effects are of interest to experts and their transformation and future are the subject of reflection. They also affect the correlation between them. 


\section{Historical aspects of the relationship between social and voluntary work}

Radková ${ }^{1}$ states that social and voluntary work are directly and indirectly connected historically as well as culturally and in terms of civilisation. Doing something for others that does not arise directly from obligations or law was and always will be a voluntary act, an act of the free will, of a free person.

Similarly, Havrdová ${ }^{2}$ notes that all helping professions originated historically as voluntary activities. Originally there had always been some idea, an enthusiasm for improving things, or for some form of assistance. However, the greater the complexity of the activity and the possibility of harm to clients, or in other words the more knowledge and a systematic approach is required, the quicker this turns into a particular profession when united with education.

Sherr ${ }^{3}$ divides the historical relationship of social and voluntary work into three stages. Even though he is making his analysis in an American context, the same forms of voluntary and social work can be identified in the European and with minor differences in the Slovak context. The following stages are:

- Volunteering as a basis for the formation of social work,

- Social work efforts to professionalization and definition of itself.

- Harmonisation of mutual relations between voluntary and social work.

\section{Volunteering as a basis for the formation of social work}

During a long period of the Middle Ages, the scope for personal activity and philanthropy was limited by the Christian doctrine, which, while supporting love for one's fellow man in theory, in practice forcefully steered away possible acts of love and used them solely for political gain. Furthermore, we are still dealing with an order to love, and goodwill, as the inner disposition at the heart of voluntary service, and external commands and conditions are mutually exclusive. Similarly by tying help, support and later insurance services for individuals to a worldly power or state we leave no room for immediate and flexible responses to specific people and situations even if there is a will to intervene on the behalf of the person in need. As this political directive is to be seen in the social sphere both in the Middle Ages up until the early modern age, so also it is evident in connection with neo-paternalism in various countries and totalitarianism in the $20^{\text {th }}$ century. The basic impetus for the concept of voluntary service as a way of activity for all people

L. Radková, Sociálna práca v tretom sektore, Trnava 2003.

P. Koucká, Dobrovolnici versus profesionálové, Psychologie dnes, 2007, No. 2, pp. 34-37.

M. Sherr, Social Work with Volunteers, Chicago 2008. 
without distinction is formed in the ideas of the Enlightenment, whereby it is not only a question of an enlightenment with social overtones, but also of highlighting the value of the human being as such without reference to his/her political, religious, professional, or social affiliation. Enlighteners seek a new justification for the necessity of cooperation and reciprocity and they emphasize the ethical level of solving imperfections and tribulations that we have caused and will still cause during the course of history. Ethics becomes a universal tool for finding enduring solutions for things human to which every endeavour must pay homage. It is not a coincidence that society in this period begins to focus intently on the problems of education, healthcare, social security of the elderly, the sick, the young and the unemployed. This turnabout changed how environmental problems were perceived among individuals who began, in this way, to be confronted and challenged into attitudes and action by people and situations that presented a particular need, thereby overthrowing stereotypes and conformity to standards that had often been used to self-limit them in the social sphere. The Enlightenment brought ideas but mainly the justification behind civil and human rights. During this period there is a paradigm shift in the perception of man suffering from deficiencies of various kinds, social helplessness, traumas, infirmity and degradation. This paradigm shift is particularly reflected in the field of law. The basic principle of modern criminal and civil law is the fact that the purpose of the law is not to take revenge on the culprit, but to admonish and correct, and compensate the victims $s^{4}$. We owe that to the social philosophers of the $18^{\text {th }}$ century. It was no longer about restriction but about looking for ways to support a person's positive qualities in correcting things. The issue was stimulating the will of the person from whom society, and in the final analysis, he himself expected a solution of the situation. The political product of these efforts became the Declaration of human and civil rights (1789). The declaration calls for responsibility and activity. One begins to understand the significance of this responsibility and activity, which is of increasing value, if one's motive is selfless, or voluntary. The second incentive was the Universal declaration of human rights (1948) and, stemming from this, the process of three generations of human rights. The boom of voluntary organizations which we can subsequently observe in the second half of the twentieth century is, amongst other things, the result of the end of the golden age of the social welfare state. Responsibility is transferred to civil society as an independent organism. The beginnings of the formation of social work as a free-standing profession are tied with charitable, philanthropic and voluntary activities. At the end of the $19^{\text {th }}$ and

4 A. Harrington et al., Moderní sociálni teorie, Praha 2006, pp. 66-67. 
the beginning of the $20^{\text {th }}$ century, in the United States of America, the UK and Germany, organized aid to poor and otherwise socially disadvantaged people was developed by means of civic and church organizations, provided in particular by volunteers under the guidance of staff. Voluntary service as a principle attempts to present the human being beyond the framework of the legal aspects of claiming rights to something; it implies a common bond on the level of moral principles, virtues and the common good. This heralds to a great extent the trend in community types of co-organization and togetherness, or rather the common good for the community or locality. The historical manifestation of this development are the emerging voluntary organisations and self-help groups, which, however, were the product of the efforts from the period of movements for the various rights of various persons, minorities, women, unemployed etc., at the end of $19^{\text {th }}$ and the first half of the $20^{\text {th }}$ century. It is clearly more demanding to engage society as a whole in voluntary service, identification with its purposes, values and goals. At present, it is obvious that neither the welfare state, nor the free market bring the desired effect $^{5}$ in the social sphere, whether in terms of people with shortages or in need or in terms of social stratification. Hospitals, clinics and schools did not ensure security, health and education in all aspects and, indeed, in certain respects these institutions retained control, dictatorship and surveillance over them. The ideas of utilitarianism as a principle of liberal social progress (its visions) threatened rather than protected freedom of thought, inquiry, self-expression and creativity. This deficit of self-expression and creativity is covered nowadays by volunteering or voluntary activities.

When compared to Western countries, the development of social work in the territory of former Hungary during that period was different, but as far as the beginning of voluntary work is concerned it was very similar at the same time. As Brnula ${ }^{6}$ notes, among the first legislative measures adopted in the territory of former Hungary was in support of activity meant for the benefit of resolving social issues to be carried out on a voluntary basis as in Western countries.

\section{Professionalization of social work and its definition}

Systems of care for the poor at the end of $19^{\text {th }}$ and beginning of $20^{\text {th }}$ century were, on the one hand, built on the work of volunteers but on the other hand, they were a transition from an individual and voluntary philanthropy to professional and scientific social work. The recognition of the need for an individual and compre-

5 Ibidem.

6 P. Brnula, Sociálna práca. Dejiny, teória a metódy, Bratislava 2012. 
hensive assessment and for solving the situations of people in distress and for the effective coordination of the services have led to the need for experts who are professionally trained for the job. However, professional preparation in its early days never aimed to replace individual interest and voluntary effort. Mary Richmond $(1908)^{7}$, for example, believed that social workers can never themselves be servants or helpers of community. She believed that the fundamental responsibility of social work as a profession is to lead and to support volunteer effort.

Nevertheless, with the development and systematisation of social services, in many areas the importance of reciprocal partnership between the social workers and professional workers and the volunteers was soon forgotten.

The beginning of the $20^{\text {th }}$ century and the period between the wars is characterised in social work in the American and both the European and Slovak contexts by the development of education in this area, with the rise of social work in different areas, and at the same time it may be defined as the period of social work efforts to define itself as an independent profession. In the context of this effort not only the appearance of social work is changing, but also there are changes in its relationship to volunteering. In an effort to demonstrate social work as a profession in relation to the colleagues of other professions, but also in relation to the clients and the society and, of course, to itself, it was necessary to clearly distinguish social work from voluntary social work efforts. As Gambrill ${ }^{8}$ states, the result of the efforts of social work to define itself was a departure from its relationship with volunteers, because through this relationship its professional status in society could be easily called into question. This way social work defined itself separately from its volunteer basis. Partnership with volunteers in providing services and solving social problems gave the volunteers access to the area of social welfare services that social work had fought for so hard and through which it is seen as a professional authority.

Tratner (1999) ${ }^{9}$ summarizes the shift in the relationship between social and voluntary work at the beginning of $20^{\text {th }}$ century in the US context: volunteering has not completely disappeared from social work, the first reason being its long tradition, and the second being that both social workers and nurses needed the power, influence and financial aid of volunteers. However, what happened was that there was an exchange of roles. While in the early days volunteers were in direct contact with those in need, paid workers ensured the functioning of the

M. Sherr, op. cit.

8 E. Gambrill, Social Work: An Authority-Based Profession, Research on Social Work Practice, Vol. 11, 2001, No. 2, pp. 166-175.

9 M. Sherr, op. cit. 
organisation, and gradually an exchange of these roles came about. Volunteers were doing office work, and as members of the boards they shaped the policy of organisations and sought financial contributions, while the fieldwork was in the hands of paid professionals. Previously perceived as a civic obligation, volunteering has become a privilege supported by agencies for those who accepted their authority and discipline.

Beside the efforts to professionalize social work, the formalisation of social work had an influence also over the change in relationship between social work and volunteering. Many of the services provided by volunteers and private subjects are falling into government hands. The government assumes responsibility for the area of social services and social work becomes its primary profession of provision. As a consequence, the work of volunteers is falling into the background.

Similarly as in the USA and in the European context, in Slovakia also during the period of the first Czechoslovak Republic, the social work went through the process of professionalization. Social workers often had to prove and defend their status in relation to the public and other professions. In Slovakia the need to define social work from other forms of aid has also arisen, in addition to the efforts of social work to distinguish itself from the charity work with which, as reported by Brnula $^{10}$, the social work was getting into the conflict in this period ${ }^{11}$.

In spite of the formalisation and professionalization of social work, the mutual cooperation of volunteers and professional workers and workers in most areas of social work was much needed in the interwar period. As Matoušek and Šustová ${ }^{12}$ state, in relation to the situation of the interwar social work during the first Czechoslovak Republic, the volunteers have many times performed the roles of conciliators, negotiators between the professionals and carers.

Cnaan ${ }^{13}$ describes the relationship of social and voluntary work in this period as one in which social workers provide systematic and professional services while volunteers make up the hidden network of security and aid.

\section{Harmonisation of relations between volunteering and social work}

Despite the changes stated in relation to volunteering and social work it can be concluded that social work never quite broke off ties with volunteers. As Ander-

\footnotetext{
10 P. Brnula, op. cit.

11 In this case it is important to note that volunteering is not identical to charitable work. Working with volunteers has its place in social as well as in charitable work. Volunteers may be involved in pursuing the objectives of both forms of assistance.

12 O. Matoušek et al, Základy sociálni práce, Praha 2001.

13 R.M. Cnaan, The Newer Deal: Social Work and Religion in Partnership, Columbia 1999.
} 
son and Ambrosino (1992) ${ }^{14}$ state, during the Second World War, social workers turned to volunteers as a necessary source of meeting the social needs. In the 1950s volunteers become partners for supplementary services of social work, they help to raise money, to educate, and they assist in offices. In the 1960s some volunteers went to the provision of direct services, they offered therapies, counselling within the framework of telephone crisis intervention, advocacy in domestic violence cases and participation in self-help groups.

The significant development of voluntary organisations, volunteer programs and self-help groups in the nineteen-seventies, contributed to a change in the mutual relations between voluntary and social work in the world. This development was triggered by the crisis of the welfare state on the one hand, and on the other hand by the policy of the conservative systems of Ronald Regan and Margaret Thatcher, which created the central part of the strategy from the support of the voluntary sector with the aim of reducing government spending on social affairs (M. Thatcher, for example, proposed to retain social care entirely on a volunteer basis). Although such a situation was characteristic mainly for the conservative systems of England and the United States, it drew the attention of other European countries (Salamon 2000) ${ }^{15}$. On the other side, the growing movement of volunteerism and self-help groups was an expression of the growing civil self-confidence and people's efforts to solve problems themselves and by applying their own visions and ideas. At the same time, it was a response to the imperfect or lack of professional services.

The return of social work to utilizing the aid of volunteers was built on the idea that adequately prepared and supervised volunteers can complement the work of social workers, and help them concentrate on the more complex aspects of their work $^{16}$.

The harmonisation of relations between social work and volunteering arrives on the territory of Slovakia much later than in Western countries. In the period following 1948 under the influence of socialism and communism in Slovakia social work as a professional activity as well as voluntary activities are decimated. Their reciprocal relationship during this period is difficult to analyse and reliably define therefore.

Social work in this period gets into the hands of the government and is fully dependent on the authorities, also being financed by them. In our opinion, the co-

\footnotetext{
14 M. Sherr, op. cit.

15 D. Ondrušek et al., Čitanka pre pokročilé neziskové organizácie, Bratislava 2000.

16 M. Sherr, op. cit.
} 
operation of government social workers and volunteers was unique in this period and was generated more by the individual effort of specific social workers. This fact is also connected with changes in the field of volunteering. The development of organisations of the civil sector and voluntary activities was interrupted first by the German occupation and the Second World War, and later by the establishment of a socialist republic. As Tošner and Sozanská ${ }^{17}$ point out, the tradition of volunteering was forcefully interrupted during the totalitarian regime and the activity of all types of independent organisations was deliberately and systematically reduced or was subject to strict control.

After 1989 in Slovakia there is a significant development in both spheres in the sphere of social work and in volunteering. Social work starts to develop quantitatively and qualitatively, on all perceived levels, as a practical activity and profession, as a science, and also as a field of study. At the same time, there is a development in volunteering and voluntary activities. The sense of freedom to make decisions about oneself and about the community led the people in Slovakia not only to establish many political parties but also non-governmental organisations and to voluntary involvement on behalf of other people and communities. The development of civil society brought with itself the development of the volunteering phenomenon. In some areas, such as humanitarian or charitable work, the space for full implementation had just opened up, but in the majority of civil and voluntary activities a new tradition emerged. In our opinion the following processes were particularly important for the formation of the reciprocal relationship between social and voluntary work:

- an elimination of national paternalism from social policy and transferral of responsibilities to the citizens,

- a transformation of the social security system and the system of social services,

- a transformation of public administration,

- a de-institutionalisation of social services,

- a development of new types of social services and social work in the field.

The processes noted above created the preconditions for the mutual cooperation of social work and volunteering.

${ }_{17}$ J. Tošner, O. Sozanská, Dobrovolníci a metodika práce s nimi v organizacích, Praha 2002. 


\section{Volunteering as part of social work at present time}

Hustinx and Handy ${ }^{18}$ indicate that social work views volunteering as part of everyday life. In this sense volunteering may be considered as one of the instruments for fulfilling its mission. As Matulayová ${ }^{19}$ notes, "supporting the development of volunteering among people is turning out to be one of the options for solving the social problems of today".

In connection to a definition of social work's mission we encounter in the most recent scientific literature the concept of social functioning. Despite the fact that social functioning is a term with multiple meanings, the authors mostly use it to refer to interactions that are taking place between the requirements of the environment and people. In this context it is possible to perceive volunteering as a path towards the development of individuals' potential resulting in support of their social functioning. It presents the intervention of social work in relation to clients who can be the recipients as well as the agents of voluntary activities. At the same time, it is an intervention directed towards the creation of the clients' living conditions, partly in the sense of improving the quality of social services of organisations, and partly in building an inclusive society.

In connection with volunteering in the context of social work, we meet with the theme of the professionalization and de-professionalization of social work. Navrátil ${ }^{20}$ writes about professionalization and de-professionalization as the dilemma of social work. Professionalization is a reflection of the efforts of the professional group to introduce standards, typification and control to its performance. As Rezníček ${ }^{21}$ states, the pursuit of social work de-professionalization should give even laymen open access to social work. Social services provided by friends, family and volunteers, according to proponents of de-professionalization, can lead to more significant results then a specialized approach.

In our opinion, the current provision of services by professionals and volunteers may not be in conflict. It does not have to be the option of either/or, i.e. it does not have to present the dilemma of being obliged to choose between two alternatives. The system of voluntary and informal assistance can be provided in compliance with the professional services and their objectives.

18 F. Handly, L. Hustinx, The Why and How of Volunteering, Nonprofit Management and Leadership, Vol. 19, 2009, No. 4, Summer 2009, pp. 549-558.

${ }_{19}$ T. Matulayová, Fenomén dobrovolníctva optikou andragogiky a sociálnej práce, [in:] Fenomén dobrovolníctva v sociálnych službách. Zbornik prispevkov, Prešov 2011, pp. 10-11.

20 O. Matoušek et al, op. cit.

21 I. Řezníček, Metody sociální práce, Praha 1994. 
Volunteer programmes can be used as a part of the services of social work in different ways. The help of volunteers can be provided concurrently with professional services; however, it may precede or follow professional help. Analysis of the benefits of volunteering and the cooperation of professional social workers with volunteers may be part of a wide range of activities of social work.

As Brueggemann ${ }^{22}$ reports, partnership with volunteers is an alternative way for social workers to work on development and provision of their services. Social workers need to perceive volunteers as partners who aim to bring in social change. Instead of experts providing services or agents representing large bureaucratic institutions, social workers can work together with volunteers and support them and direct them towards ensuring social and economic justice.

We agree with Mrázová and Radkováa ${ }^{23}$ that voluntary service neither necessarily nor exclusively means amateurism. Groups of volunteers are springing up in the form of well-coordinated professional teams of experts who are willing and committed to serving those who most need it. They are able to give shape to alternative concepts of public and social policy, and deal with advocacy and lobbying activities. They reveal gaps in social assistance and respond swiftly to societal needs whether on a national, regional or local level.

Social work and volunteering are developing in a post-industrial period that is significantly influenced by the modernisation process. These influences in the area of social as well as voluntary work are a subject of interest to experts and reflection about their changes and future. They also influence their mutual relations.

Chytil ${ }^{24}$, in his opinion on the results of modernisation in relation to social work, agrees with Stoesz (1997) who anticipates an end of social work based on the fact that it originated during the period of industrialisation and missed the transition to a post-industrial society. He notes in his conclusion, on the other hand, that social work might perhaps survive if its objectives would be redefined towards the sustainment and development of communities through the community economy. Social work can take advantage of its experience in establishing a community of people of equal standing who will protect one other in situations when the modernised society will fail to do so.

22 W.G. Brueggeman, The Practice of Macro Social Work, Belmont 2002.

23 A. Mrázová, L. Radková, Dobrovolnictvo a postupná profesionalizácia jeho manažmentu ako priorita rozvoja sociálnej práce, Geriatria, Vol. 7, 2007, No. 4, pp. 170-173.

24 O. Chytil, Di̛sledky modernizace pro sociální práci, Sociální práce/Sociálna práca, vol. 7 , 2007, No. 4, p. 64- 71. 
As Göppner and Hämäläinen ${ }^{25}$ note, the development of managerialism is a reflection of modernisation and globalisation trends, and is becoming an expressive form of a new post-modern ideology of social work. Social work is becoming more and more a system of organisations, and management of "services packages and networks", including assessment and risk, cost estimate and analysis of costs and profits. The authors point out in this context that if, on the one hand, social work does not want to compromise its own professional existence, it has to think in categories of efficiency, effectiveness, quality and management, and therefore reflect the economic-business thinking. On the other hand, as Bauer ${ }^{26}$ points out, the fact must be considered that the provision of services in the social arena is occurring in relation to people in an interactive endeavour that is in progress, and happening in the same place and involved are two people or groups of people with differing needs. General transference of economic categories onto social work, as well as development of concepts for the management of organisations in the social sphere, ultimately always requires specification and adjustment, by taking into consideration professional objectives whose benefit they should be serving, at the end of the day.

We disagree with the theory about the demise of social work. In our opinion, social work responds to current changes in the post-modern society, reflected by the development of community work and its preventive and development potential in relation to diverse target groups and to various areas of social practice. The values of social work built on a foundation of human rights and social justice are particularly relevant in an age of post-modern individualism. Proof of this is the adoption of the document called the Global Agenda - the world challenge for social work and social development in March 2012 by the International Federation of Social Workers (IFSW), the International Association of Schools of Social Work (IASSW), and by the International Council for Social Welfare (ICSW). The document is based on the fact that the political, economic, cultural and social structure of the past and the present results in unequal consequences for communities at the global, national and local level, and has a negative impact on people. As a result of this, it calls for the need to enforce and defend such a societal structure that pays attention to respect for human rights and dignity and is interested in the quality of human relations. For the period 2012-2016 they propose focusing the efforts of social workers on four areas:

25 H.J. Göppner, J. Hämäläinen, Rozprava o vede o sociálnej práci. Hladanie prvkov pre programatiku, Bratislava 2008.

26 Ibidem. 
- promoting social and economic equality,

- promoting the dignity and value of the human being,

- making an effort to achieve a sustainable environment,

- strengthening understanding of the importance of human relationships.

In each of these areas measures are proposed towards building and supporting strong and inclusive local communities, whereby the importance of community work is underlined.

The consequences of social modernisation affect not only the field of social work, but also the area of volunteering. Some theories see in the results of modernisation a "threat" to the area of public participation and identify trends of decreasing voluntary effort in all groups of the population, but especially in the young generation. In particular, the root causes are being looked for in increasing individualism, in the collapse of traditional local networks and communities, diminishing ties to religion, the fostering of a consumer lifestyle, or individuals becoming cut off from "the outside world". Studies show that trends related to modernisation are not reflected automatically in a decline in people's participation but in changes in the so-called volunteering formulas or styles. Similarly as in the field of social work, we encounter two tendencies in the field of volunteering. On the one hand, a need for the professionalization of volunteering is identified, chiefly in terms of development of formal, management-directed volunteering. On the other hand, there is a development of community style volunteering, whether in a formal, non-formal or virtual community setting ${ }^{27}$.

Both of these trends from the field of volunteering may be reflected in the context of social work. The subject of interest for social work, in our view, is both formal and informal volunteering. Both, however, find their use in different areas of social work. Formally managed volunteering is a part of the theory, research and practice level of individual and group social work. Informal volunteering is a part of theory, research and practice in community social work in particular. See Figure 1.

27 P. Frič, M. Vávra, Tri tváre komunitního dobrovolnictví, Praha 2012. 
Figure 1. Volunteering in the context of social work
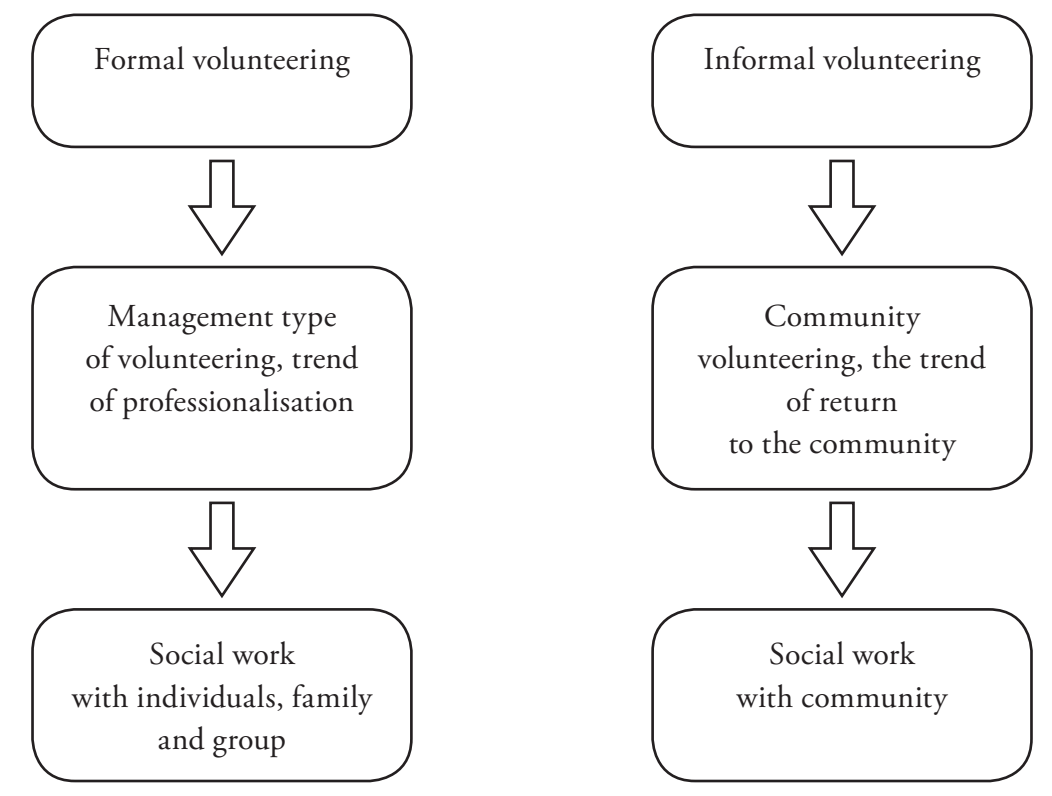

Source: Own work.

Formally organised and managed volunteering has developed in the last few years, especially in the field of social and health care. An emphasis on a managerial style of leadership in volunteering, and the associated trend of professionalization of work with volunteers especially correlates to the nature of formally organised and professionally based social work. Professionalized volunteering in the area of social work focuses primarily on the clients - individuals, families and groups. As Fric $^{28}$ notes, it seems that the symbiosis of these two models is unshakable and has great potential for further development.

At the same time, beside the trend for professionalization of management volunteering, we encounter the trend of a so-called "return to community" and the development of informal voluntary activities. A number of authors state that the importance of non-formal community volunteering, aimed at strengthening and developing local or interest-based community, will rise in the future. In this context,

28 P. Frič, Současné trendy dobrovolnictví a sociální práce, Sociálna práca/Sociální práce, Vol. 11, 2011, No. 4, p. 8. 
we agree with Frič ${ }^{29}$, that the future of volunteering in the field of social work could be linked to an even greater use of self-regulatory elements and a closer connection of social and community work. The mutual relations between formal and informal volunteering suggest that, in the field of work with volunteers, social work with individuals and groups can be linked with working with the community.

\section{Conclusion}

Societal processes related to the modernisation of society change the attitudes of people in relation to volunteering, and they present new challenges for social work. We agree with Sherr ${ }^{30}$, that social work in the world as well as in the Slovak setting has the potential to begin a new era in its relation to volunteering and volunteers. Over the past two decades the area of social services has changed significantly. Responsibility for the provision of social services is shifting from government to private and non-profit sectors at the local level. Along with this shift there is an effort to encourage volunteers to participate in fulfilling social needs. Social work is an important profession in the development, provision and evaluation of social services. Its future as an effective and valued profession is significantly linked to how it will renew its role of partner alongside volunteers.

29 Ibidem, p. 9.

30 M. Sherr, op. cit. 